RESEARCH

\title{
Directly measured free and total 25-hydroxyvitamin D levels in relation to metabolic health in multi-ethnic postmenopausal females in Saudi Arabia
}

\author{
Shatha Alharazy ${ }^{101}$, M Denise Robertson², Susan Lanham-New², Muhammad Imran Naseer ${ }^{3,4}$, \\ Adeel G Chaudhary $3,4,5$ and Eman Alissa ${ }^{6}$

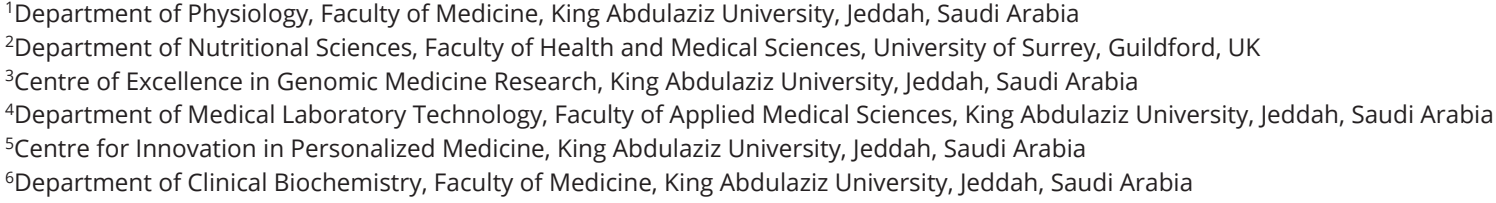

Correspondence should be addressed to S Alharazy: smalharazy@kau.edu.sa

\begin{abstract}
Background: Measurement of free 25-hydroyvitamin D (25(OH)D) status has been suggested as a more representative marker of vitamin $D$ status than that of total 25(OH)D. Previously, free 25(OH)D could only be calculated indirectly; however, a newly developed direct assay for the measurement of free 25(OH)D is now available. The aim of this study therefore was to investigate directly measured total and free vitamin $D$ levels association with metabolic health in postmenopausal healthy women living in Saudi Arabia.

Methods: A sample of 302 postmenopausal women aged $\geq 50$ years $(n=302)$ living in Saudi Arabia were recruited in a cross-sectional study design. Blood samples were collected from subjects for measurement of serum levels of total 25(OH)D, directly measured free $25(\mathrm{OH}) \mathrm{D}$, metabolic bone parameters, lipid profile, and other biochemical tests.

Results: A positive correlation was found between directly measured free and total $25(\mathrm{OH}) \mathrm{D}(r=0.64, P<0.0001)$. Total but not free 25(OH)D showed significant association with serum intact parathyroid hormone $(P=0.004)$, whilst free $25(\mathrm{OH}) \mathrm{D}$ but not total 25(OH)D showed a significant association with total cholesterol and LDL-C $(P=0.032$ and $P=0.045$, respectively).

Conclusions: Free 25(OH)D and total 25(OH)D were found to be consistently correlated but with different associations to metabolic health parameters. Further research is needed to determine which marker of vitamin D status would be the most appropriate in population studies.
\end{abstract}




\section{Introduction}

Vitamin D plays an important role in numerous human metabolic functions including calcium (Ca) and phosphorus $\left(\mathrm{PO}_{4}\right)$ hemostasis and bone growth and remodeling (1, 2). vitamin $\mathrm{D}$ stimulates $\mathrm{Ca}$ and $\mathrm{PO}_{4}$ absorption from the intestines, suppresses the production of parathyroid hormone (PTH), and enhances the renal tubular absorption of $\mathrm{Ca}$ and mobilization of $\mathrm{Ca}$ and $\mathrm{PO}_{4}$ from bone $(3,4,5$, 6). Vitamin D is not only vital for skeletal health but also involved in several extra-skeletal functions. Vitamin D deficiency has been associated with obesity, cardiometabolic risk, diabetes, age-related diseases, and autoimmune diseases $(7,8,9,10,11)$. Additionally, there is emerging evidence that vitamin D sufficiency may be related to prevention of several pathological conditions including cardiovascular diseases, malignancies, autoimmune diseases, as well as severity of COVID19 $(12,13)$.

Vitamin D (in the form of vitamin D3) is primarily synthesized in the skin from a cholesterol derivative (7-dehydrocholeterol) reliant on UV-B radiation from exposure to the sun $(14,15,16)$. Whether vitamin D is obtained from sunlight, from the diet, or through supplementation, 25-hydroxyvitamin D $(25(\mathrm{OH}) \mathrm{D})$ is considered as the major vitamin $\mathrm{D}$ metabolite that accurately represents vitamin D status $(17,18)$.

In healthy individuals, approximately $85-90 \%$ of vitamin $\mathrm{D}$ is bound to vitamin D-binding protein, with a low percentage (10-15\%) being bound loosely to albumin, while the remainder $(<1 \%, 0.03 \%)$ is said to be free (19). Based on the 'free hormone hypothesis', free $25(\mathrm{OH}) \mathrm{D}$ is the only form of $25(\mathrm{OH}) \mathrm{D}$ that is capable of cellular uptake and metabolism (20); hence, free $25(\mathrm{OH}) \mathrm{D}$ might be a more 'appropriate surrogate marker' for evaluating vitamin D status $(21,22)$. This hypothesis is confirmed by the finding that mice without vitamin D-binding protein who were expected to have deficient vitamin D levels subsequently did not show any indication of vitamin $\mathrm{D}$ deficiency but only when they were fed with vitamin D-deficient diet (23). It has been proposed that measuring total vitamin D might in fact be misleading in the assessment of vitamin D status in certain conditions such as liver and kidney diseases and that measuring free vitamin D might be more precise in evaluating vitamin $\mathrm{D}$ status in populations with more than one ethnic group $(19,24)$. For instance, it has been found that despite the lower total 25(OH)D levels in Black Americans in comparison with White Americans/Europeans, free 25(OH)D was not lower, thus explaining the stronger bone health found in Black individuals and adding credence to the hypothesis that free $25(\mathrm{OH}) \mathrm{D}$ might be superior to total in representing physiological vitamin D status $(25,26,27)$. Free $25(\mathrm{OH}) \mathrm{D}$ can be measured either by means of a direct method, using a recently developed immunoassay, or estimated by calculation using the levels of albumin, vitamin D-binding protein and total $25(\mathrm{OH}) \mathrm{D}(20,28)$. However, although commonly performed, the estimation of free $25(\mathrm{OH}) \mathrm{D}$ by the calculation method does not precisely represent the directly measured free $25(\mathrm{OH}) \mathrm{D}$ levels in several clinical situations (19).

Therefore, we aimed in this study to investigate total and directly measured free $25(\mathrm{OH}) \mathrm{D}$ association with metabolic health including bone metabolic parameters and lipid profile (primarily), lifestyle, and socio-demographic factors including ethnicity (secondarily). The study was conducted in a random cohort of multi-ethnic (white Middle Eastern and black African) postmenopausal women living in western Saudi Arabia where vitamin D deficiency is an extremely prevalent issue despite a high level of sunlight.

\section{Methods}

\section{Subjects and study design}

This is a cross-sectional study carried out in a sample of 302 postmenopausal women (age $\geq 50$ years) in Jeddah, Saudi Arabia, (August 2018 to September 2019).

\section{Sample size calculation}

The total number of females of age range between 50 and 79 years in the western area of Saudi Arabia is approximately 430,739 , according to the latest demographic survey of the general Saudi authority for statistics (https://www.stats. gov.sa/en) (29). The prevalence of vitamin D insufficiency (serum 25(OH)D <20 ng/mL; according to Institute of Medicine (IOM) (30) guidelines) among postmenopausal females in Jeddah (the western area of Saudi Arabia) is $80 \%$ (31). The maximum expected prevalence of serum vitamin D levels lower than the sufficient vitamin D level $(<20 \mathrm{ng} / \mathrm{mL})$ among those postmenopausal females is $90 \%$. The level of confidence is $95 \%$ with a study power of 0.80 . Accordingly, the calculated sample size was 240 females, as determined by a validated sample size determinant software program (Epi-Info, version 6, GA, USA). After several stages of exclusion (Fig. 1), a total of 302 women were collected for this study.

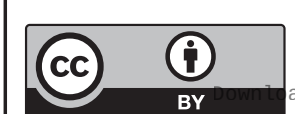

This work is licensed under a Creative Commons Attribution 4.0 International License. 


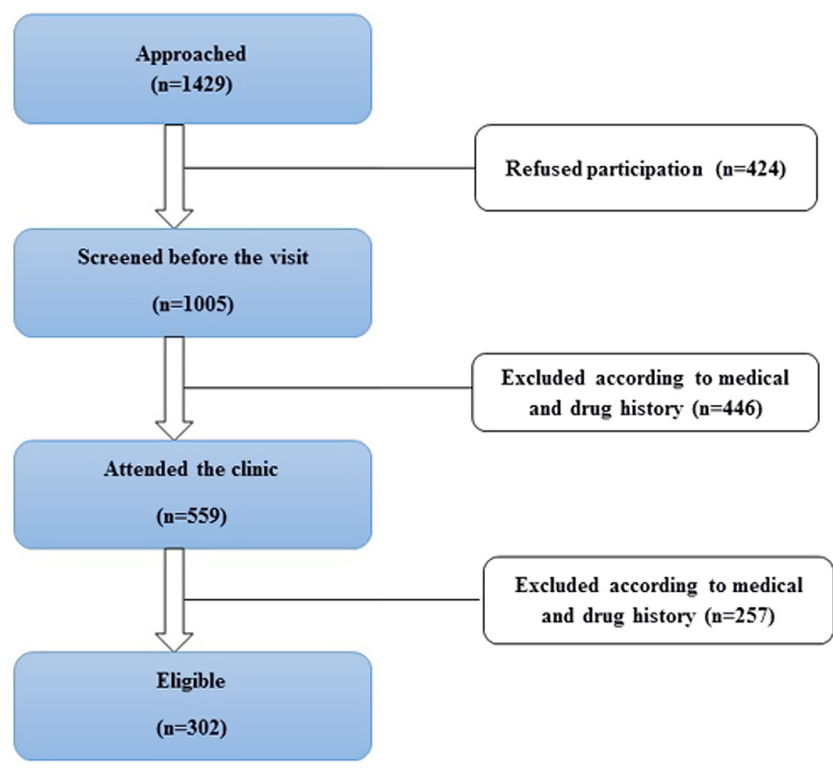

Figure 1

Flowchart of the study participants.

\section{Recruitment}

Recruitment of participating women for the current study was conducted from seven primary health care centers (PHCCs) scattered in Jeddah. Each PHCC represented one of the seven geographic divisions of Jeddah to ensure that the overall health condition of the participants will exemplify indiscriminately designated adult cohorts. We applied a multi-stage selection method. In the first stage, we designated a single PHCC representing each of the seven geographic divisions of Jeddah. In the second stage, files of the recorded female cohorts were selected by selecting randomly female samples from the designated PHCCs. In the third stage, all females in the nominated age group (50 years and above) were communicated for potential enrollment to the study with consideration of the defined inclusion criteria of this study. The sample size of randomly selected women from each center was proportionate to the number of the registered women in each center.

The study was undertaken at the Centre of Innovation in Personalized Medicine in King Fahad Medical Research Centre, King Abdulaziz University, Jeddah. A written wellinformed consent for enrollment in the study was provided by each participant. Ethical standards of Declaration of Helsinki were followed throughout the study and ethical approval to conduct the study was obtained from the Unit of Biomedical Ethics, Center of Excellence in Genomic Medicine Research, King Abdulaziz University (05-CEGMRBioeth-2018).

Postmenopausal status for this study was defined as the ceasing of the menses for a period of 1 year and above, with a level of serum follicular-stimulating hormone greater than $15 \mathrm{IU} / \mathrm{L}$. Exclusion criteria included history of chronic renal and liver disease, cancer, rheumatoid arthritis, malabsorption syndrome, hyperthyroidism, hyperparathyroidism, diabetes, or drug history including medications with potential influence on vitamin D levels (e.g. glucocorticoids, vitamin D supplements and anticonvulsants). Women with high levels of liver enzymes and creatinine were precluded (the normal clinical level of serum aspartate aminotransferase $<45 \mathrm{U} / \mathrm{L}$; alanine aminotransferase $<50 \mathrm{U} / \mathrm{L}$ and alkaline phosphatase between 80 and $280 \mathrm{U} / \mathrm{L}$; the normal level of serum creatinine in females $<105 \mu \mathrm{mol} / \mathrm{L}$ ). Women with thyroidstimulating hormone levels below $0.465 \mathrm{mIU} / \mathrm{L}$ were also excluded.

\section{Study protocol and data collection}

Each participant completed a questionnaire (filled by the researcher) requesting data on medical history, drug history, menstrual history, socio-demographic (including ethnicity and skin tone), and lifestyle history (including sun exposure, veiling, dietary vitamin D intake, physical activity, and smoking habits).

Skin tone was noted for all participants relying on Fitzpatrick skin tone categorization (32). Use of sunscreen and extent (number of hours per week) of outdoor sunlight exposure in the past month was recorded for each participant. To evaluate parity, the total number of children was recorded for each participant. In consideration of the age group involved in the study, as well as the lifestyle of Saudi Arabia, a minimum of 30 min brisk walking (moderate aerobic activity) at least five times a week was considered as a cut-off for a reasonable form of exercise to be asked to the participants in the questionnaire (33).

In Saudi Arabia, the majority of women (particularly the elderly) wear cape and veil either for religious or cultural motives. Participating females covering their body and head while exposing their hands and face were regarded as partially covered, whereas females who covered their body and face while exposing hands and eyes were defined as totally covered.

Vitamin D dietary intake per day was assessed using semi-quantitative food frequency questionnaire (34). Food items included in the questionnaire included yogurt, milk, buttermilk, eggs, tuna, salmon, sardines, and beef liver as they are the most frequently consumed food rich in vitamin D in Saudi Arabia. Food frequency intake was presented as number of servings per day, week, or month. Vitamin D daily dietary intake in international

This work is licensed under a Creative Commons Attribution 4.0 International License. ded from Bioscientifica.com at 04/26/2023 12:22:54PM 
units was then appraised to compare it with the estimated average requirement which is 600-800 IU/day according to the IOM reference for females aged 50 years and above (30).

\section{Blood collection and laboratory analysis}

Blood samples were collected from each participant after an overnight fast. Serum free $25(\mathrm{OH}) \mathrm{D}$ was analyzed in duplicate by two steps immunoassay using ELISA kit (KAPF1991, Future Diagnostics Solutions B.V., Wijchen, Netherlands) with intra and inter-assay coefficient of variations (CVs) being between 5.3 and 6.4\%. The first step of free $25(\mathrm{OH}) \mathrm{D}$ immunoassay was the incubation in which free $25(\mathrm{OH}) \mathrm{D}$ bound to the anti-vitamin $\mathrm{D}$ antibody was coated on the well of the microtiter plate. A specific amount of biotinylated $25(\mathrm{OH}) \mathrm{D}$ was added to each well after washing then the unbound biotinylated $25(\mathrm{OH}) \mathrm{D}$ was washed away and a streptavidin peroxidase conjugate was added. The second step was addition of chromogenic substrate. Lastly, the reaction was terminated by adding stop solution then absorbance (at $450 \mathrm{~nm}$ ) is measured by a plate spectrophotometer.

Serum intact PTH and total $25(\mathrm{OH}) \mathrm{D}$ were quantified by direct competitive chemiluminescence immunoassay, using a LIASON auto-analyzer (DiaSorinInc, Stillwater, MN, USA) with intra and inter-assay CVs being 5.5 and $7.8 \%$ for serum total $25(\mathrm{OH}) \mathrm{D}$ and 4.9 and $4.5 \%$ for serum intact PTH, respectively. Vitamin D status was classified according to IOM guidelines (30): vitamin D sufficiency as 25 $(\mathrm{OH}) \mathrm{D}$ concentration range between 20 and $50 \mathrm{ng} / \mathrm{mL}$ or between 50 and $125 \mathrm{nmol} / \mathrm{L}$, vitamin D insufficiency as the $25(\mathrm{OH}) \mathrm{D}$ concentration between 12 and $19 \mathrm{ng} / \mathrm{mL}$ or between 30 and $49 \mathrm{nmol} / \mathrm{L}$, and vitamin $\mathrm{D}$ deficiency as the $25(\mathrm{OH}) \mathrm{D}$ concentration $<12 \mathrm{ng} / \mathrm{mL}$ or $30 \mathrm{nmol} / \mathrm{L}$.

Serum albumin, creatinine, $\mathrm{Ca}, \mathrm{PO}_{4}$, magnesium, lipid profile, blood glucose, liver enzymes (alanine aminotransferase, aspartate aminotransferase and alkaline phosphatase) were all measured using a VITROS 250 Clinical Chemistry auto-analyzer (Ortho-Clinical Diagnostics Inc., Rochester, NY, USA) with intra and interassay CVs less than 5\%.

Serum LDL-C concentrations were assessed by calculations performed by the analyzer, using Friedewald equation (35) reliant on the obtained concentration of direct HDL-C, total cholesterol, and triglycerides. VLDL-C concentrations were calculated as the triglycerides level divided by 2.2 .

Serum thyroid function test (free triiodothyronine, free thyroxin, and thyroid-stimulating hormone) and follicular-stimulating hormone levels were analyzed by immunoassays, using VITROS ECiQ (OrthoClinical Diagnostics Inc.) with intra and inter-assay CVs below $4 \%$.

\section{Statistical analysis}

SPSS program (v.25 SPSS Chicago Inc., 2011) was used for statistical analysis of data of this study. KolmogorovSmirnov test was used to test the normality of the data. All numerical parametric results were expressed as means \pm S.D., while numerical non parametric results were presented as median (IQR). Descriptive results were expressed as a percentage of the total sample number. Spearman correlation was used to obtain associations between various parameters as data were not normally distributed. 25(OH)D levels were compared between groups using Kruskal-Wallis H test. Post hoc test (Dunn's test) was utilized to determine which group was unlike from other. Statistical significance was determined at $P$-value of $\leq 0.05$. Multiple stepwise regression analysis was conducted to find out potential predictors of vitamin D level as the dependent variable, with all independent variables that exhibited significant bivariate associations at $P$-value of $\leq 0.05$.

\section{Results}

The data concerning the general characteristics of the women taking part in this study are shown in Table 1. Serum levels of total and free $25(\mathrm{OH}) \mathrm{D}$ and screening biochemical parameters are shown in Tables 2 and 3 .

Based on IOM vitamin D cut-off values (30), the participants were classified as $29 \%(n=87)$ with vitamin D deficiency $(25(\mathrm{OH}) \mathrm{D}<12 \mathrm{ng} / \mathrm{mL}), 31 \%(n=94)$ with vitamin D insufficiency (25(OH)D level of $12-19 \mathrm{ng} / \mathrm{mL})$, while $40 \%$ $(n=121)$ had sufficient levels of vitamin D $(25(\mathrm{OH}) \mathrm{D}$ level of $20-50 \mathrm{ng} / \mathrm{mL})$. In our study population, total $25(\mathrm{OH}) \mathrm{D}$ and free $25(\mathrm{OH}) \mathrm{D}$ levels were not significantly associated with ethnicity $(P=0.13$ and $P=0.66$, respectively) (Table 2). In addition, they did not show any significant association with other sociodemographic factors $(P>0.05)$ (data not shown).

Asignificant correlation was found between free $25(\mathrm{OH})$ $\mathrm{D}$ and total 25(OH)D $(r=0.57, P=0.001)$ (Fig. 2A). There was also a significant correlation between free $25(\mathrm{OH}) \mathrm{D}$ and total $25(\mathrm{OH}) \mathrm{D}$ among both White and Black groups ( $r=0.59, P=0.001$ and $r=0.44, P=0.023)$, respectively (Fig. 2B and C). After stratification according to ethnicity,

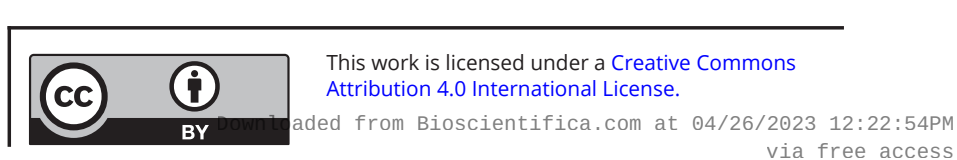


Table 1 General characteristics of the participants. Numerical data are described as mean \pm S.D. with normal distribution and as median (IQR) with non-normal distribution. Descriptive data are presented as $n(\%) . \%$ is percentage out of the total number of subjects.

\begin{tabular}{|c|c|c|c|c|c|}
\hline \multirow[b]{2}{*}{ Variables } & \multicolumn{5}{|c|}{ Results $(n=459)$} \\
\hline & Median & IQR & Mean & S.D. & $n(\%)$ \\
\hline Age (years) & 58 & $53-63$ & & & \\
\hline Age at menopause (years) & 50 & $48-53$ & & & \\
\hline Years since menopause & 7 & $3-14$ & & & \\
\hline Weight (kg) & & & 75.2 & 16 & \\
\hline Height (cm) & & & 154.3 & 6.5 & \\
\hline $\mathrm{BMI}\left(\mathrm{kg} / \mathrm{m}^{2}\right)$ & & & 31.5 & 7 & \\
\hline Waist circumference $(\mathrm{cm})$ & 90 & 84-99 & & & \\
\hline Hip circumference $(\mathrm{cm})$ & 110 & $102-119$ & & & \\
\hline Waist-hip ratio & 0.82 & $0.78-0.86$ & & & \\
\hline
\end{tabular}

Obesity classes*

Normal (BMI: $18.5-24.9 \mathrm{~kg} / \mathrm{m}^{2}$ )

$42(14 \%)$

$85(28 \%)$

$103(34 \%)$

$45(15 \%)$

$27(9 \%)$

$187(62 \%)$

Central obesity (Waist-hip ratio $\geq 0.8$ )

Ethnicity ${ }^{\dagger}$

White (Arabic)

Black (African)

$263(87 \%)$

South Asian (Pakistani)

$28(9 \%)$

$11(4 \%)$

Marital status

Single

Married

Divorced

Widow

$15(5 \%)$

$166(55 \%)$

$30(10 \%)$

$91(30 \%)$

Education

Illiterate

Elementary

Intermediate

Secondary

University

Postgraduate

$82(27 \%)$

$73(24 \%)$

$45(15 \%)$

$54(18 \%)$

$36(12 \%)$

$12(4 \%)$

Occupation

Housewife

Governmental employed

$263(87 \%)$

Privately employed

Retired

Physical activity

Yes

$12(4 \%)$

$3(1 \%)$

$24(8 \%)$

$97(32 \%)$

No

Smoking

Yes

No

Hypertensive (according to their medical records)

Yes

No

Use of sunscreen

Dietary vitamin D intake (IU/day)

110

60-169

$205(68 \%)$

$21(7 \%)$

$281(93 \%)$

$103(34 \%)$

$199(66 \%)$

$0(0 \%)$

$0(0 \%)$

average requirement

Vitamin D status ${ }^{\S}$

Optimal

$121(40 \%)$

$94(31 \%)$

$87(29 \%)$

Deficient

*Obesity classifications are based on the World Health Organization obesity definitions $(36,37) .{ }^{\dagger}$ Ethnicity was self-reported. ${ }^{*}$ Estimated average requirement for women aged 50 years and over based on Institute of Medicine (IOM) recommendation (600-800 IU/day) (30). ${ }^{5}$ Vitamin D staus is classified according to $25(\mathrm{OH})$ D cut-off levels of IOM (30) (serum total $25(\mathrm{OH})<12 \mathrm{ng} / \mathrm{mL}$ deficiency, $12-19 \mathrm{ng} / \mathrm{mL}$ insufficiency, and 20-50 ng/mL optimal level).

https://ec.bioscientifica.com

https://doi.org/10.1530/EC-21-0445 (c) 2021 The authors Published by Bioscientifica Ltd

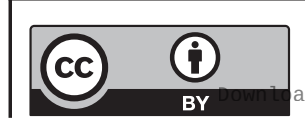

This work is licensed under a Creative Commons Attribution 4.0 International License.

ded from Bioscientifica.com at 04/26/2023 12:22:54PM 
Table 2 Serum levels of total and free 25(OH)D in overall and as classified by ethnicity. Difference between different ethnic groups were tested by Kruskal-Wallis $\mathrm{H}$ test.

\begin{tabular}{|c|c|c|c|c|c|c|}
\hline \multirow[b]{2}{*}{ Subjects } & \multicolumn{2}{|c|}{ Total 25(OH)D (ng/mL) } & \multicolumn{2}{|c|}{ Free $25(\mathrm{OH}) \mathbf{D}(\mathrm{pg} / \mathrm{mL})$} & \multicolumn{2}{|c|}{$\begin{array}{l}\text { Percentage of free } 25(\mathrm{OH}) \mathrm{D} \text { out of total } \\
\qquad 25(\mathrm{OH}) \mathrm{D}(\%)^{\star}\end{array}$} \\
\hline & Median & IQR & Median & IQR & Median & IQR \\
\hline Overall $(n=302)$ & 17.6 & $10.6-24.4$ & 4.32 & $3.29-5.72$ & 0.026 & $0.018-0.033$ \\
\hline White $(n=263)$ & 18 & $11.25-25.3$ & 4.33 & $3.31-5.79$ & 0.026 & $0.019-0.033$ \\
\hline Black $(n=28)$ & 11.75 & $9.27-21.65$ & 4.14 & $2.83-5.45$ & 0.028 & $0.021-0.038$ \\
\hline Asian $(n=11)$ & 17.1 & $12.3-21.6$ & 4.03 & $3.62-5.27$ & 0.024 & $0.017-0.032$ \\
\hline$P$-value for trend & 0.131 & & 0.658 & & 0.588 & \\
\hline
\end{tabular}

*Percentage of free $25(\mathrm{OH}) \mathrm{D}$ out of the total 25(OH)D was calculated by dividing free $25(\mathrm{OH}) \mathrm{D}$ levels in ng/mL over total 25(OH)D level in ng/mL then multiplied by 100 .

25(OH)D, 25-hydroxyvitamin D.

Asian race was excluded due to small frequency (only 11 participants).

Univariate analysis of total $25(\mathrm{OH}) \mathrm{D}$ and free 25(OH)D with bone-related parameters, anthropometric, and blood pressure parameters are shown in (Table 4). Total 25(OH)D in all studied women collectively was correlated inversely with intact PTH and positively with serum $\mathrm{PO}_{4}(r=-0.18, P=0.004$ and $r=0.13, P=0.026$, respectively). Similarly, total 25(O)D in White individuals was also inversely associated with serum intact PTH and positively with serum $\mathrm{PO}_{4}(r=-0.29, P=0.001$ and $r=0.14, \quad P=0.026$, respectively) and serum albumin $(r=0.13, P=0.04)$. Conversely, in Black individuals, no association was found between total $25(\mathrm{OH})$ and bone parameters. Importantly, no significant correlation was observed between free 25(OH)D level and bone parameters measured in this study. In addition, total and free $25(\mathrm{OH}) \mathrm{D}$ showed no association with BMI, waist circumference, hip circumference, waist-hip ratio, systolic blood pressure, or diastolic blood pressure in all participants collectively and in both White and Black ethnic groups. The data were tested to determine if there was any correlation between vitamin D status (total and free $25(\mathrm{OH}) \mathrm{D}$ ) and lipid profile parametersincluding totalcholesterol, triglyceride, HDL-C, LDL-C and VLDL-C. Total 25(OH)D was not associated with the lipid profile (Spearman's two-tailed correlation: $P=0.71 ; r=-0.022$ for total cholesterol, $P=0.085 ; r=-0.10$ for triglyceride, $P=0.54 ; r=0.036$ for HDL-C, $P=0.95$; $r=-0.004$ for LDL-C and $P=0.35 ; r=-0.056$ for VLDL-C). On the other hand, free $25(\mathrm{OH}) \mathrm{D}$ was inversely associated with only total cholesterol and LDL-C $(P=0.032, r=-0.13$ and $P=0.045, r=-0.12$, respectively) (Fig. $3 \mathrm{~A}$ and $\mathrm{B}$ ).

Total 25(OH)D and free 25(OH)D associations with skin tone, veiling type, parity, and sun exposure are shown

Table 3 Biochemical characteristics of study subjects.

\section{Variable}

Serum intact PTH $(\mathrm{pg} / \mathrm{mL})$

Serum albumin (g/L)

Serum Ca $(\mathrm{mmol} / \mathrm{L})$

Serum corrected $\mathrm{Ca}(\mathrm{mmol} / \mathrm{L})$ *

Serum $\mathrm{PO}_{4}(\mathrm{mmol} / \mathrm{L})$

Serum magnesium ( $\mathrm{mmol} / \mathrm{L})$

Fasting blood glucose ( $\mathrm{mmol} / \mathrm{L})$

Serum follicular-stimulating hormone (IU/L)

Serum thyroid-stimulating hormone (mIU/L)

Serum free triiodothyronine $(\mathrm{ng} / \mathrm{dL})$

Serum free T3 $(\mathrm{pg} / \mathrm{mL})$

Serum total cholesterol $(\mathrm{mmol} / \mathrm{L})$

Serum triglyceride $(\mathrm{mmol} / \mathrm{L})$

Serum HDL-C $(\mathrm{mmol} / \mathrm{L})$

Serum LDL-C (mmol/L)

Serum VLDL-C (mmol/L)

\begin{tabular}{cc}
\hline \multicolumn{2}{c}{ Results $(n=\mathbf{3 0 2})$} \\
\cline { 1 - 2 } 23.7 & IQR \\
\hline 43 & $14.2-42$ \\
2.49 & $40-48$ \\
2.43 & $2.37-2.64$ \\
1.36 & $2.37-2.48$ \\
0.8 & $1.24-1.51$ \\
5.6 & $0.8-0.9$ \\
51.9 & $5.2-6.2$ \\
2.37 & $39-67.8$ \\
1.18 & $1.39-3.7$ \\
3.72 & $1.04-1.33$ \\
5.10 & $3.26-4.13$ \\
1.27 & $4.50-6$ \\
1.30 & $0.94-1.8$ \\
3.07 & $1.10-1.6$ \\
0.58 & $2.62-3.8$ \\
& $0.43-0.83$ \\
\hline
\end{tabular}

*Corrected Ca was calculated as serum Ca 0.02 (40-serum albumin).

25(OH)D, 25-hydroxyvitamin D; Ca, calcium; HDL-C, high density lipoprotein cholesterol; LDL-C, low density lipoprotein cholesterol; $\mathrm{PO}_{4}$, phosphate; PTH, parathyroid hormone; VLDL-C, very low density lipoprotein cholesterol.

https://ec.bioscientifica.com

https://doi.org/10.1530/EC-21-0445 (c) 2021 The authors Published by Bioscientifica Ltd

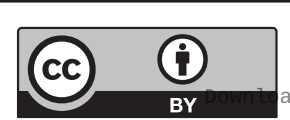

This work is licensed under a Creative Commons Attribution 4.0 International License. ded from Bioscientifica, com at $04 / 26 / 2023$ 12:22:54PM 

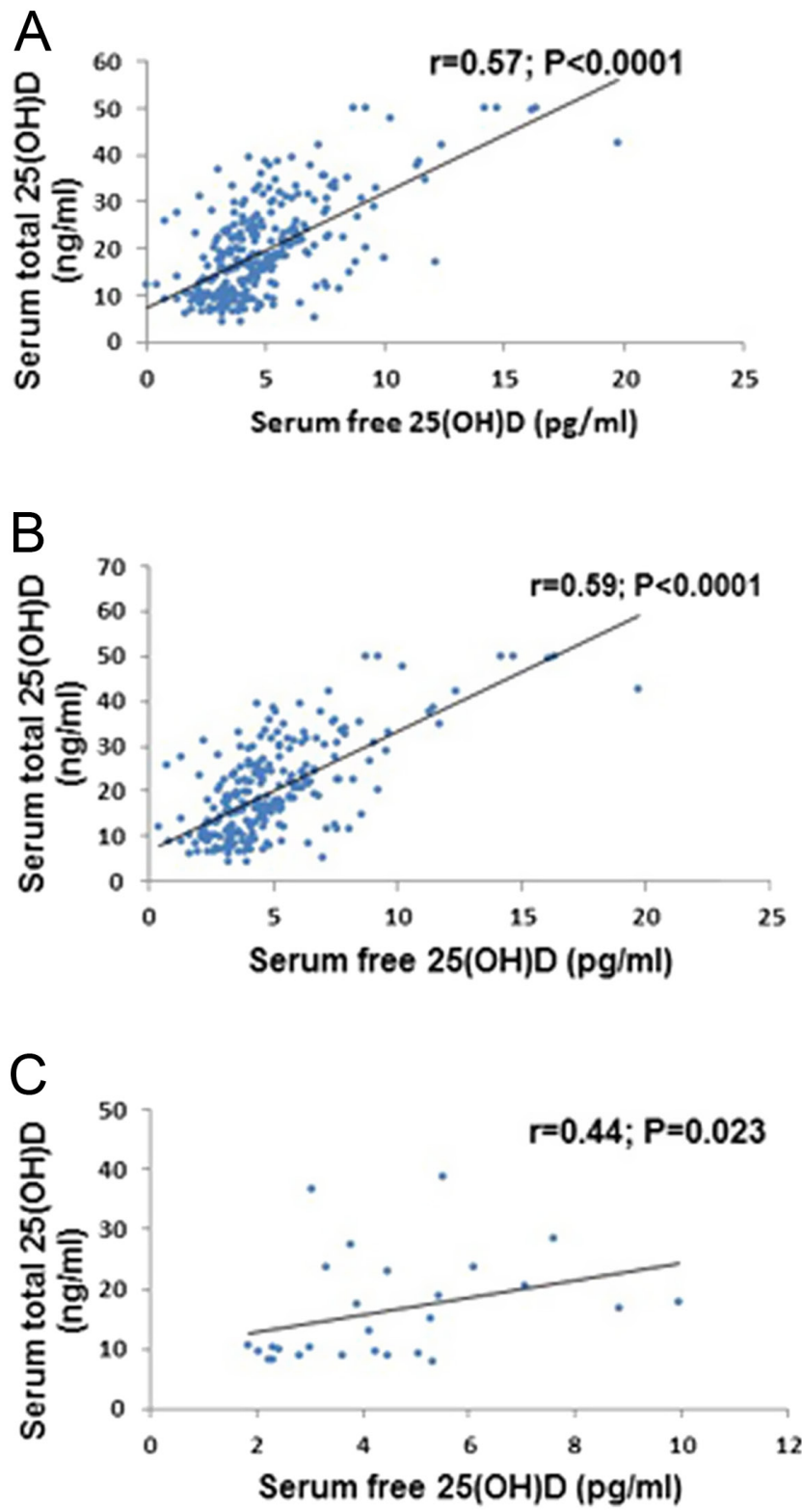

Figure 2

The relationship (Spearman's correlation, two-tailed) between free 25(OH)D and total 25(OH)D. (A) In all study subjects $(n=302)$. (B) In White subjects $(n=263)$. (C) in Black subjects $(n=28)$.

in Table 5 for all subjects as whole. No significant differences were observed in total 25(OH)D in groups classified by skin tone, veiling type, parity, and sun exposure. In comparison, a significant free 25(OH)D difference was found between the groups of skin tone and veiling $(P=0.001$ and $P=0.012$, respectively) but not between parity or sun exposure groups ( $P=0.17$ and $P=0.32$, respectively) (Table 5$)$. Post hoc testing showed that free $25(\mathrm{OH}) \mathrm{D}$ in type II skin tone group is significantly different than in type III $(P<0.001)$, IV $(P<0.001)$, and V $(P=0.006)$. Additionally, the median free $25(\mathrm{OH}) \mathrm{D}$ was higher in the partially covered women than in the totally covered group.

Multiple variables including anthropometric measures, blood pressure, skin tone, veiling, bone parameters, vitamin D supplementation, serum total cholesterol, and LDL-C level were tested by regression analysis. Multiple linear regression showing potential predictors of vitamin D status including total and free 25(OH)D are summarized in Table 6. Serum intact PTH and serum $\mathrm{PO}_{4}$ were statistically significant as predictors of serum total $25(\mathrm{OH}) \mathrm{D}$ levels, explaining $4.9 \%$ of the variance in serum total $25(\mathrm{OH}) \mathrm{D}$ levels. Alternatively, skin tone showed statistical significance as a predictor of free $25(\mathrm{OH}) \mathrm{D}$ status, contributing $2.2 \%$ of the variance in serum free $25(\mathrm{OH}) \mathrm{D}$.

\section{Discussion}

Free $25(\mathrm{OH}) \mathrm{D}$ (whether it is directly measured or calculated) was positively correlated with total $25(\mathrm{OH}) \mathrm{D}$, which has been reported previously in other populations groups $(19,38,39)$. Our data also support these findings. Regardless of the race or ethnic origin, total 25(OH)D in our study was associated significantly $(P<0.0001)$ with directly measured free $25(\mathrm{OH}) \mathrm{D}$, which was consistent with observations found in United Kingdom and United States White individuals as well as African Americans and Gambians (39). However, when we investigated the association between total and free 25(OH)D with metabolic health parameters as well as socio-demographic and lifestyle factors, we found that free $25(\mathrm{OH}) \mathrm{D}$ did not behave entirely as total $25(\mathrm{OH}) \mathrm{D}$. Free $25(\mathrm{OH}) \mathrm{D}$ (but not total) did not show an association with intact PTH; however, it did show an association with some parameters of lipid profile (total cholesterol and LDL-C), skin tone, and veiling which total 25(OH)D did not.

$\mathrm{PTH}, \mathrm{Ca}$, and $\mathrm{PO}_{4}$ are crucial markers related to bone health and bone metabolism. Serum intact PTH and $\mathrm{PO}_{4}$ were predictors for total 25(OH)D status in this study. The observed association between total $25(\mathrm{OH}) \mathrm{D}$ and $\mathrm{PTH}$ was not surprising as it has been previously extensively reported in the literature $(38,40,41)$. In regards to the association between free $25(\mathrm{OH}) \mathrm{D}$ with bone-related parameters, our finding was in line with two studies (measuring directly free 25(OH)D) that reported lack of any significant association between free $25(\mathrm{OH}) \mathrm{D}$ and PTH $(27,42)$. However, it has been reported in several other studies that free $25(\mathrm{OH}) \mathrm{D}$ is inversely associated with PTH in a similar way to that of total $25(\mathrm{OH}) \mathrm{D}(38,43,44,45,46)$.

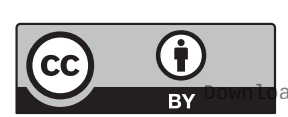

This work is licensed under a Creative Commons Attribution 4.0 International License. 
Table 4 Serum total and free 25(OH)D level association with anthropometric measures, blood pressure, and bone metabolic parameters. Total and free 25(OH)D association data are presented as $r(P)$. All correlations were obtained by two-tailed Spearman's correlation.

\begin{tabular}{|c|c|c|}
\hline \multirow[b]{2}{*}{ Variable } & \multicolumn{2}{|c|}{ Overall $(n=302)$} \\
\hline & Total 25(OH)D & Free $25(\mathrm{OH}) \mathrm{D}$ \\
\hline BMI $\left(\mathrm{kg} / \mathrm{m}^{2}\right)$ & $\begin{array}{c}-0.057 \\
(0.33)\end{array}$ & $\begin{array}{c}-0.007 \\
(0.90)\end{array}$ \\
\hline Waist circumference $(\mathrm{cm})$ & $\begin{array}{c}-0.073 \\
(0.22)\end{array}$ & $\begin{array}{l}0.035 \\
(0.56)\end{array}$ \\
\hline Hip circumference (cm) & $\begin{array}{c}-0.077 \\
(0.20)\end{array}$ & $\begin{array}{c}0.008 \\
(0.89)\end{array}$ \\
\hline Waist-hip ratio & $\begin{array}{c}0.009 \\
(0.88)\end{array}$ & $\begin{array}{c}0.04 \\
(0.49)\end{array}$ \\
\hline Systolic blood pressure (mmHg) & $\begin{array}{c}-0.09 \\
(0.16)\end{array}$ & $\begin{array}{r}-0.031 \\
(0.63)\end{array}$ \\
\hline Diastolic blood pressure (mmHg) & $\begin{array}{l}-0.12 \\
(0.067)\end{array}$ & $\begin{array}{c}-0.041 \\
(0.51)\end{array}$ \\
\hline Serum intact PTH (pg/mL) & $\begin{array}{c}-0.183^{*} \\
(0.004)^{*}\end{array}$ & $\begin{array}{l}-0.008 \\
(-0.90)\end{array}$ \\
\hline Serum albumin (g/L) & $\begin{array}{c}0.099 \\
(0.091)\end{array}$ & $\begin{array}{c}-0.086 \\
(0.14)\end{array}$ \\
\hline Serum Ca (mmol/L) & $\begin{array}{c}-0.006 \\
(0.92)\end{array}$ & $\begin{array}{c}-0.074 \\
(0.20)\end{array}$ \\
\hline Serum $\mathrm{PO}_{4}(\mathrm{mmol} / \mathrm{L})$ & $\begin{array}{c}0.13^{*} \\
(0.026)^{*}\end{array}$ & $\begin{array}{c}0.078 \\
(0.18)\end{array}$ \\
\hline Serum magnesium (mmol/L) & $\begin{array}{c}-0.001 \\
(0.99)\end{array}$ & $\begin{array}{l}-0.10 \\
(0.083)\end{array}$ \\
\hline
\end{tabular}

\begin{tabular}{|c|c|}
\hline \multicolumn{2}{|c|}{ White ethnic group $(n=263)$} \\
\hline Total 25(OH)D & Free 25(OH)D \\
\hline-0.043 & -0.019 \\
\hline$(0.49)$ & $(0.76)$ \\
\hline-0.12 & 0.004 \\
\hline$(0.055)$ & (0.95) \\
\hline-0.094 & -0.007 \\
\hline$(0.14)$ & $(0.92)$ \\
\hline-0.03 & 0.03 \\
\hline$(0.64)$ & $(0.63)$ \\
\hline-0.124 & -0.095 \\
\hline$(0.07)$ & $(0.16)$ \\
\hline-0.13 & -0.062 \\
\hline$(0.057)$ & $(0.36)$ \\
\hline$-0.285^{*}$ & 0.047 \\
\hline$(0.001)^{*}$ & $(0.49)$ \\
\hline $0.13^{*}$ & -0.052 \\
\hline$(0.04)^{*}$ & $(0.41)$ \\
\hline 0.035 & -0.072 \\
\hline (0.59) & $(0.25)$ \\
\hline $0.14^{*}$ & 0.074 \\
\hline$(0.026)^{*}$ & $(0.26)$ \\
\hline 0.052 & -0.071 \\
\hline$(0.4)$ & $(0.26)$ \\
\hline
\end{tabular}

\begin{tabular}{|c|c|}
\hline \multicolumn{2}{|c|}{ Black ethnic group $(n=28)$} \\
\hline Total 25(OH)D & Free 25(OH)D \\
\hline-0.001 & 0.10 \\
\hline$(0.10)$ & $(0.62)$ \\
\hline 0.25 & 0.21 \\
\hline$(0.21)$ & $(0.32)$ \\
\hline 0.021 & 0.046 \\
\hline (0.92) & $(0.83)$ \\
\hline 0.37 & 0.32 \\
\hline (0.066) & $(0.12)$ \\
\hline-0.048 & -0.30 \\
\hline$(0.82)$ & $(0.15)$ \\
\hline 0.12 & -0.12 \\
\hline (0.55) & (0.57) \\
\hline-0.16 & -0.02 \\
\hline$(0.41)$ & (0.92) \\
\hline-0.005 & 0.26 \\
\hline$(0.98)$ & $(0.20)$ \\
\hline-0.069 & 0.21 \\
\hline$(0.73)$ & (0.29) \\
\hline 0.17 & -0.099 \\
\hline (0.39) & $(0.62)$ \\
\hline-0.08 & -0.16 \\
\hline$(0.68)$ & $(0.41)$ \\
\hline
\end{tabular}

*Significant correlation $(P<0.05)$.

25(OH)D, 25-hydroxyvitamin D; BMI, body mass index; Ca, calcium; $\mathrm{PO}_{4}$, phosphate; PTH is parathyroid hormone.

These conflicting data could be attributed to several confounding factors affecting the relationship between vitamin D status and bone parameters such as age, sex, genetic variations, ethnicity, and even methodology used to measure total $25(\mathrm{OH}) \mathrm{D}$. Reports on links between free 25(OH)D and bone markers are still conflicting and under debate. A very recent randomized-control trial in elderly $(n=221)$ reporting an association of both free and total 25(OH)D with PTH and lack of association with $\mathrm{Ca}$ and bone turnover markers has concluded that no superiority of free $25(\mathrm{OH}) \mathrm{D}$ over total in evaluating markers of bone health (47). Overall, free 25(OH)D measurement in our results is not showing any superiority or advantage over the standard measurement of total vitamin $\mathrm{D}$ in respect to bone parameters. In fact, total $25(\mathrm{OH}) \mathrm{D}$ may be more appropriate in terms of detecting an association with bone metabolic parameters.

Raised PTH levels which are usually regarded as one of the indicators of vitamin D deficiency are more frequently seen in Black individuals than in White individuals (48). Additionally, the association between total 25(OH)D and PTH might be dissimilar in Black individuals and White individuals (49). In support with that, when our study subjects were categorized into White individuals and Black individuals, the previously observed associations between total $25(\mathrm{OH}) \mathrm{D}$ with bone parameters in all subjects collectively disappeared in Black individuals compared to White individuals that showed similar observed overall associations between vitamin D status and bone parameters. Our failure to find in Black individuals any association between vitamin D status and PTH levels was in agreement with what was found by Aloia et al. (27). This confirms the role of ethnicity in influencing vitamin D relationship with bone health.

Vitamin D deficiency has been linked with risk of cardiovascular diseases (50). Previous studies report a negative association between total 25(OH)D levels and cardiovascular risk markers and atherogenic lipid profile $(51,52)$. A review by Jorde et al. (52), comparing vitamin D status with lipid levels in 22 cross-sectional studies, found that total 25(OH)D was positively associated with LDL-C and HDL-C, positively or negatively associated with total cholesterol, and negatively associated with triglycerides. In contrast to this, our study did not find an association between total 25(OH)D and any of the measured lipid profile parameters. Free $25(\mathrm{OH}) \mathrm{D}$, however, was inversely associated with serum total cholesterol and LDL-C levels $(r=-0.125, P=0.032$ and $r=-0.117, P=0.045$, respectively). 
A
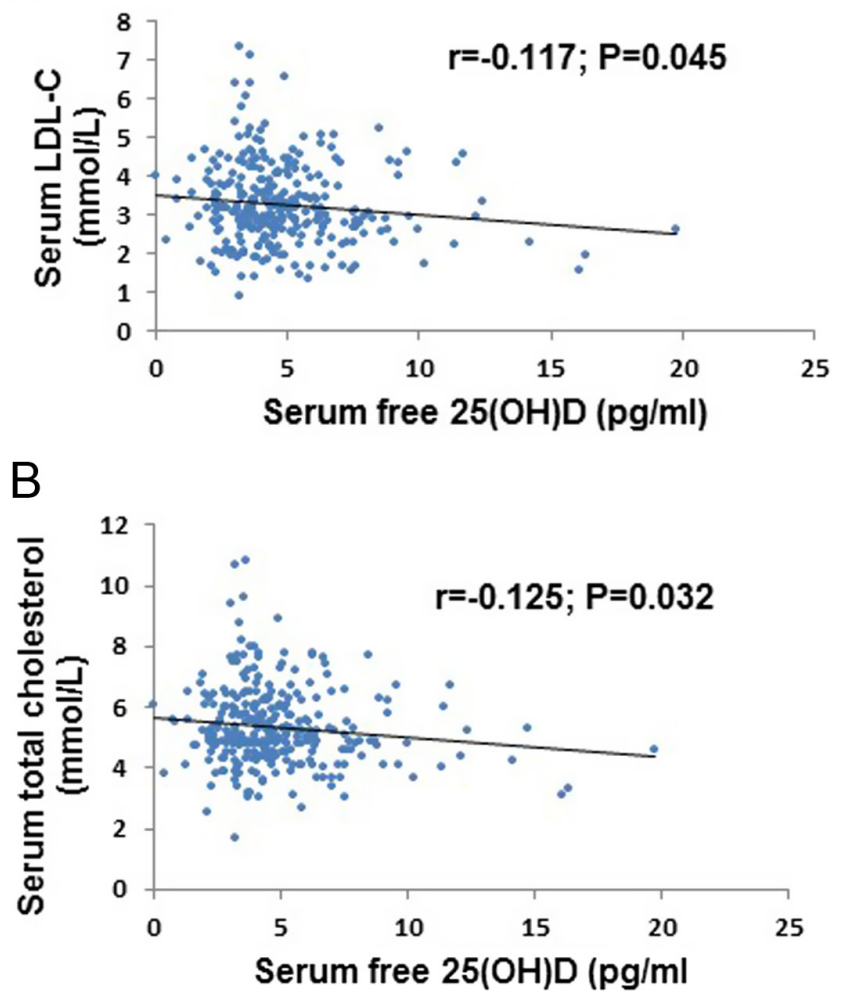

Figure 3

The significant relationship (Spearman's correlation, two-tailed) between free $25(\mathrm{OH}) \mathrm{D}$ and lipid profile in all study subjects $(n=302)$. (A) The relationship between free $25(\mathrm{OH}) \mathrm{D}$ and serum total cholesterol. (B) The relationship between free $25(\mathrm{OH}) \mathrm{D}$ and serum LDL-C.

Data on directly measured free 25(OH)D level and how it relates to lipid parameters is very limited in the literature. Most epidemiological studies relating vitamin $\mathrm{D}$ with cardiovascular risk are centered on total $25(\mathrm{OH}) \mathrm{D}$ only (53). Although our results of free $25(\mathrm{OH})$ relationship with lipid levels are inadequate to draw a definitive conclusion, free $25(\mathrm{OH}) \mathrm{D}$ exhibited a different relationship with lipids when compared with total 25(OH)D. However, whether future assessment of free $25(\mathrm{OH}) \mathrm{D}$ instead of total $25(\mathrm{OH}) \mathrm{D}$ can afford a new vision toward cardiovascular risk is still unclear. Additional research in this area is certainly needed.

Synthesis of vitamin D in the skin is influenced by many factors including age, skin coverage, the use of sunscreen, and skin pigmentation (54). People with darker skin tones tend to have lower circulating vitamin D levels as elevated skin melanin pigment hinders the penetration of UV sunrays and prevents consequent vitamin D dermal synthesis (55). In addition, housebound subjects and women who cover their body and/head while being outdoor for cultural or religious reasons, as the case in the participants of our study, are improbable to get sufficient vitamin D from sunrays $(56,57)$. Interestingly, free $25(\mathrm{OH}) \mathrm{D}$ in this study was associated with skin tone, with free 25(OH)D level being higher in the lighter type II skin tone group compared to the darker skin tone groups (skin type III, IV, and V). Supporting this, former studies found that vitamin $\mathrm{D}$ levels can vary according dermal melanin levels as melanin acts as a natural sunscreen (58). Individuals with darker skin color require longer duration of sun exposure to achieve similar vitamin D levels of those with lighter skin (59). It was shown by Armas et al. (55) that exposure to UV sunrays and skin type together form $80 \%$ of the differences in circulating serum levels of $25(\mathrm{OH}) \mathrm{D}$ resulted from UV sun exposure. However, the majority of studies investigating the vitamin D relationship with skin tone and sun exposure were focused on total vitamin D but not free. There is still a need to explore the free vitamin D relationship with skin tone and sun exposure. Veiling was also associated with free $25(\mathrm{OH}) \mathrm{D}$ but not with total $25(\mathrm{OH}) \mathrm{D}$. Women who were partially covered with exposing their face and hands had higher serum free $25(\mathrm{OH}) \mathrm{D}$ concentrations than women who covered their body and face with exposing their eyes and hands only. Although veiling and sun exposure are consistently reported to be linked with vitamin D status (particularly total 25(OH)D) $(1,59,60$, $61)$, veiling association with total $25(\mathrm{OH}) \mathrm{D}$ was lacking in our study. However, results in women from United Arab Emarites (62) and Jordan (63) were parallel to our results. The unobserved differences in total vitamin $\mathrm{D}$ between subgroups of veiling or sun exposure found in our study are possibly due to the majority of participants being totally veiled and not being exposed adequately to sunlight. Furthermore, the overlap between veiling and sun exposure could be another reason as both partially (all covered except face and hands) and completely veiled (all covered except eyes and hands) women were exposing small skin areas and might not be different in aspects of adequate sun exposure and vitamin D synthesis. However, the exclusive free $25(\mathrm{OH}) \mathrm{D}$ association with veiling was conflicting and an explanation for this could not be drawn. This observation might suggest that free $25(\mathrm{OH}) \mathrm{D}$ can be influenced negatively by veiling more than total, which is confusing as there was no evidence of free $25(\mathrm{OH}) \mathrm{D}$ and sun exposure relationship. An expanded future study focusing on free and total $25(\mathrm{OH}) \mathrm{D}$ relation to sun exposure and veiling (with more details on sun exposure) might be essential to determine the influence of vitamin D sunlight-dermal synthesis on actual free vitamin D levels.

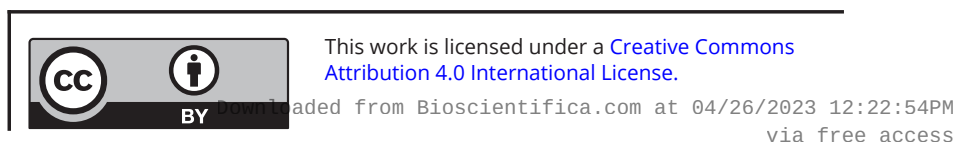


Table 5 Differences in serum total and free 25(OH)D concentrations as classified by skin tone, veiling, parity, and sun exposure. $25(\mathrm{OH}) \mathrm{D}$ difference between different groups were tested by Kruskal-Wallis $\mathrm{H}$ test. \% is percentage out of the total number of subjects.

\begin{tabular}{|c|c|c|c|}
\hline \multirow[b]{2}{*}{ Variables } & \multirow[b]{2}{*}{$n(\%)$} & \multicolumn{2}{|c|}{ Total 25(OH)D ng/mL } \\
\hline & & Median & IQR \\
\hline \multicolumn{4}{|l|}{ Skin tone (Fitzpatrick ${ }^{\dagger}$ ) } \\
\hline Type I (light, pale white) & $3(1 \%)$ & 9.5 & $9-10$ \\
\hline Type II (white, fair) & $42(14 \%)$ & 20.45 & $10.6-31.7$ \\
\hline Type III (medium white to olive) & $97(32 \%)$ & 19.75 & $12.1-24.6$ \\
\hline Type IV (olive, mid brown) & $127(42 \%)$ & 16.6 & $11.5-24.3$ \\
\hline Type $\mathrm{V}$ (brown, dark brown) & $27(9 \%)$ & 10.95 & $9.4-19.7$ \\
\hline Type VI (very dark brown, black) & $6(2 \%)$ & 28.4 & $15.1-30.4$ \\
\hline$P$-value for trend & & 0.055 & \\
\hline \multicolumn{4}{|l|}{ Veiling type } \\
\hline Totally covered, only eyes exposed & $236(78 \%)$ & 17.1 & $10.4-23.8$ \\
\hline Partially covered, face exposed & $66(22 \%)$ & 19.85 & $11.8-26.9$ \\
\hline$P$-value for trend & & 0.34 & \\
\hline \multicolumn{4}{|l|}{ Parity } \\
\hline No children & $27(9 \%)$ & 16.4 & $11-22.5$ \\
\hline 1-2 children & $30(10 \%)$ & 19 & $12.9-23.5$ \\
\hline 3-4 children & $57(19 \%)$ & 17 & $10.7-24.9$ \\
\hline 5-6 children & 97 (32\%) & 16.5 & $9.6-23.8$ \\
\hline 7+ children & $91(30 \%)$ & 18.7 & $12-27.9$ \\
\hline$P$-value for trend & & 0.48 & \\
\hline \multicolumn{4}{|l|}{ Sun exposure } \\
\hline$<1 \mathrm{~h} /$ week & $218(72 \%)$ & 17.7 & $10.7-24.3$ \\
\hline 1-2 h/week & $42(14 \%)$ & 13.8 & $8.9-25.5$ \\
\hline 2-3 h/week & $15(5 \%)$ & 13.8 & $10.2-20$ \\
\hline$>3 \mathrm{~h} /$ week & $27(9 \%)$ & 20.7 & $13.5-24.6$ \\
\hline$P$-value for trend & & 0.18 & \\
\hline
\end{tabular}

\begin{tabular}{|c|c|}
\hline \multicolumn{2}{|c|}{ Free $25(\mathrm{OH}) \mathrm{D} \mathrm{ng} / \mathrm{mL}$} \\
\hline Median & IQR \\
\hline 3.51 & $3.2-3.8$ \\
\hline 5.6 & $4-7.6$ \\
\hline 4.4 & $3.3-5.4$ \\
\hline 4.1 & $3.3-5.2$ \\
\hline 3.7 & $2.8-5.3$ \\
\hline 5.5 & $5.3-7.1$ \\
\hline \multicolumn{2}{|l|}{$0.001 *$} \\
\hline 4.1 & $3.2-5.5$ \\
\hline 4.7 & $4.0-6$ \\
\hline \multicolumn{2}{|l|}{$0.012^{*}$} \\
\hline 3.6 & $2.9-4.5$ \\
\hline 4.3 & $3.5-5.1$ \\
\hline 4.1 & $3.3-6.7$ \\
\hline 4.5 & $3.7-5.7$ \\
\hline 4.5 & $3.7-5.7$ \\
\hline \multicolumn{2}{|l|}{0.17} \\
\hline 4.3 & $3.3-5.5$ \\
\hline 4.1 & $3.3-6.2$ \\
\hline 4.7 & 3-5.5 \\
\hline 5.3 & $3.5-7.1$ \\
\hline 0.32 & \\
\hline
\end{tabular}

${ }^{\dagger}$ Fitzpatrick scale $(25),{ }^{*}$ significant $25(\mathrm{OH}) \mathrm{D}$ difference $(P<0.05)$ between the groups. $\mathrm{IQR}$, inter-quartile range.

The current study has a number of strengths and limitations. Consideration of ethnicity when analyzing our vitamin D results is regarded as a point of strength. In addition, at the time that reports on actual free 25(OH)D data in general and in Saudi population particularly were inadequate. We measured free vitamin D directly instead of estimating its value by calculation as calculation methods seem to underestimate real free vitamin D. On the other hand, the current study has several limitations. First, the cross-sectional nature of the study design prevents us from determining causal relationships between vitamin
D parameters and its correlates. Secondly, the present study relied on single measurements of vitamin D and did not consider the seasonal variation of vitamin D levels. However, the abundance of sunshine throughout the year in Saudi Arabia makes the seasonal aspect less relevant than in other international cohorts. Thirdly, the small sample size of Black and Asian ethnic groups, but this factor is not easily to be controlled as our study subjects were randomly selected according to their normal distribution in the Saudi community (in Jeddah city specifically). Lastly, this research used competitive chemiluminescence

Table 6 Multiple regression analysis between serum 25(OH)D (free and total) level and independent variables.

\begin{tabular}{|c|c|c|c|c|c|}
\hline \multirow[b]{2}{*}{ Dependent variables } & \multirow[b]{2}{*}{ Independent variables } & \multirow[b]{2}{*}{$\boldsymbol{\beta}$} & \multirow[b]{2}{*}{$\mathbf{P}$} & \multicolumn{2}{|c|}{$95 \% \mathrm{Cl}$ for $\boldsymbol{\beta}$} \\
\hline & & & & Lower limit & Upper limit \\
\hline Serum total $25(\mathrm{OH}) \mathrm{D}$ & Serum intact PTH $(p g / m L)$ & -0.045 & $0.007 *$ & -0.077 & -0.012 \\
\hline Total R ${ }^{2}=0.049$ & Serum PO4 (mmol/L) & 5.644 & $0.046 *$ & 0.105 & 11.183 \\
\hline $\begin{array}{l}\text { Serum free } 25(\mathrm{OH}) \mathrm{D} \\
\text { Total } \mathrm{R}^{2}=0.022\end{array}$ & Skin tone & -0.409 & $0.01 *$ & -0.719 & -0.1 \\
\hline
\end{tabular}

95\% Cl: confidence intervals; $\beta$, unstandardized regression coefficient; $\mathrm{R}^{2}$, percent variance explained by each variable. Variable inclusion with $P<0.05$ and exclusion with $P>0.10$.

*significant $P$-value $(P<0.05)$.

https://ec.bioscientifica.com

https://doi.org/10.1530/EC-21-0445
(C) 2021 The authors Published by Bioscientifica Ltd

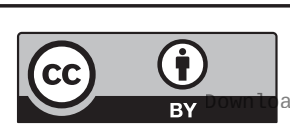

This work is licensed under a Creative Commons Attribution 4.0 International License. 
immunoassay to quantify vitamin $\mathrm{D}$ instead of using the gold standard method for measuring $25(\mathrm{OH})$, which is liquid chromatography tandem mass spectrometry.

\section{Conclusions}

Free 25(OH)D association with total 25(OH) did not appear to be affected by ethnicity. Additionally, free 25(OH)D status did not exhibit an association with PTH compared to total $25(\mathrm{OH}) \mathrm{D}$, but significant associations were seen with skin tone, veiling as well as total cholesterol and LDL-C. In conclusion, free $25(\mathrm{OH}) \mathrm{D}$ seemed not to follow total $25(\mathrm{OH}) \mathrm{D}$ in terms of association with metabolic health including bone metabolic parameters and lipid profile as well as with skin tone and veiling. More studies exploring further the role of actual free $25(\mathrm{OH}) \mathrm{D}$ in cardiovascular risk are needed as well as free $25(\mathrm{OH}) \mathrm{D}$ response to sun exposure and veiling. Moreover, additional studies are also needed to confirm the superiority of free $25(\mathrm{OH}) \mathrm{D}$ over total in the assessment of vitamin D status and its relationship to health outcomes.

\section{Declaration of interest}

The authors declare that there is no conflict of interest that could be perceived as prejudicing the impartiality of the research reported.

\section{Funding}

Joint supervision program, King Abdulaziz University, Jeddah, Saudi Arabia. The funders had no role in study design, data collection and analysis, decision to publish, or preparation of the manuscript.

\section{Ethics approval and consent to participate}

Ethical approval of this study was obtained from the Research Ethics Committee in Unit of Biomedical Ethics, Center of Excellence in Genomic Medicine Research, King Abdulaziz University (ref no. 05-CEGMR-Bioeth-2018). Fully informed, written consent was obtained from the participants.

\section{Availability of data and materials}

The datasets used and/or analysed during the current study are available from the corresponding author on reasonable request.

\section{Author contribution statement}

$\mathrm{S}$ A contributed to the study design and execution, data analysis and manuscript drafting. M D R and S L-N contributed to supervision, writing review and editing. $\mathrm{M}$ I $\mathrm{N}$ contributed to writing review. A C contributed to supervision. E A contributed to data analysis, writing review and supervision. All authors read and approved the final manuscript.

\section{Acknowledgement}

The authors are thankful for all women who participated in this study.

\section{References}

1 Holick MF. Vitamin D deficiency. New England Journal of Medicine 2007 357 266-281. (https://doi.org/10.1056/NEJMra070553)

2 Holick MF, Binkley NC, Bischoff-Ferrari HA, Gordon CM, Hanley DA, Heaney RP, Murad MH, Weaver CM \& Endocrine Society. Evaluation, treatment, and prevention of vitamin D deficiency: an Endocrine Society clinical practice guideline. Journal of Clinical Endocrinology and Metabolism 201196 1911-1930. (https://doi.org/10.1210/jc.2011-0385)

3 Holick MF \& Garabedian M. Vitamin D: photobiology, metabolism, mechanism of action, and clinical applications. In Primer on the Metabolic Bone Diseases and Disorders of Mineral Metabolism, 6th ed., pp. 106-114. Washington, DC: American Society for Bone and Mineral Research, 2006.

4 Bouillon R. Vitamin D: photosynthesis, metabolism, and action to clinical applications. In Endocrinology, 3rd ed., pp. 1009-1028. Eds L De Groot, JL Jameson \& HG Burger. Philadelphia: WB Saunders, 2001.

5 DeLuca HF. Overview of general physiologic features and functions of vitamin D. American Journal of Clinical Nutrition 200480 (Supplement) 1689S-1696S. (https://doi.org/10.1093/ajcn/80.6.1689S)

6 Holick MF. Resurrection of vitamin D deficiency and rickets. Journal of Clinical Investigation 2006116 2062-2072. (https://doi.org/10.1172/ JCI29449)

7 Barrea L, Frias-Toral E, Pugliese G, Garcia-Velasquez E, De Los Angeles Carignano M, Savastano S, Colao A \& Muscogiuri G. Vitamin D in obesity and obesity-related diseases: an overview. Minerva Endocrinology 202146 177-192. (https://doi.org/10.23736/s03911977.20.03299-x)

8 Megna M, Ferrillo M, Barrea L, Patruno C, Muscogiuri G, Savastano S, Fabbrocini G \& Napolitano M. Vitamin D and psoriasis: an update for dermatologists and nutritionists. Minerva Endocrinologica 202045 138-147. (https://doi.org/10.23736/S0391-1977.20.03190-9)

9 Ferri E, Casati M, Cesari M, Vitale G \& Arosio B. Vitamin D in physiological and pathological aging: lesson from centenarians. Reviews in Endocrine and Metabolic Disorders 201920 273-282. (https:// doi.org/10.1007/s11154-019-09522-y)

10 Wacker M \& Holick MF. Vitamin D effects on skeletal and extraskeletal health and the need for supplementation. Nutrients 20135 111-148. (https://doi.org/10.3390/nu5010111)

11 Papandreou D \& Hamid ZTN. The role of vitamin D in diabetes and cardiovascular disease: an updated review of the literature. Disease Markers 20152015 580474. (https://doi.org/10.1155/2015/580474)

12 Laird E, Rhodes J \& Kenny RA. Vitamin D and inflammation: potential implications for severity of COVID-19. Irish Medical Journal 202011381.

13 Holick MF. Vitamin D: importance in the prevention of cancers, type 1 diabetes, heart disease, and osteoporosis. American Journal of Clinical Nutrition 200479 362-371. (https://doi.org/10.1093/ajcn/79.3.362)

14 Holick MF. High prevalence of vitamin D inadequacy and implications for health. Mayo Clinic Proceedings 200681 353-373. (https://doi. org/10.4065/81.3.353)

15 Calvo MS, Whiting SJ \& Barton CN. Vitamin D intake: a global perspective of current status. Journal of Nutrition 2005135 310-316. (https://doi.org/10.1093/jn/135.2.310)

16 Norman AW. From vitamin D to hormone D: fundamentals of the vitamin D endocrine system essential for good health. American Journal of Clinical Nutrition $2008 \mathbf{8 8}$ 491S-499S. (https://doi. org/10.1093/ajcn/88.2.491S)

17 Institute of Medicine Food and Nutrition Board. Dietary Reference Intakes for Calcium and Vitamin D. Washington, DC: National Academy Press, 2011. (https://doi.org/10.17226/13050)

18 Hollis BW. Assessment of vitamin D nutritional and hormonal status: what to measure and how to do it. Calcified Tissue International 1996 58 4-5. (https://doi.org/10.1007/BF02509538)

19 Bikle DD \& Schwartz J. Vitamin D binding protein, total and free vitamin D levels in different physiological and pathophysiological conditions. Frontiers in Endocrinology 201910 317. (https://doi. org/10.3389/fendo.2019.00317)

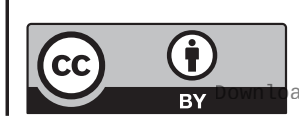

This work is licensed under a Creative Commons Attribution 4.0 International License. ded from Bioscientifica.com at 04/26/2023 12:22:54PM 
20 Bikle DD, Gee E, Halloran B, Kowalski MA, Ryzen E \& Haddad JG. Assessment of the free fraction of 25-hydroxyvitamin D in serum and its regulation by albumin and the vitamin D-binding protein. Journal of Clinical Endocrinology and Metabolism 198663 954-959. (https://doi org/10.1210/jcem-63-4-954)

21 Chun RF, Peercy BE, Orwoll ES, Nielson CM, Adams JS \& Hewison M. Vitamin D and DBP: the free hormone hypothesis revisited. Journal of Steroid Biochemistry and Molecular Biology 2014144 132-137. (https:// doi.org/10.1016/j.jsbmb.2013.09.012)

22 Johnsen MS, Grimnes G, Figenschau Y, Torjesen PA, Almås B \& Jorde R. Serum free and bio-available 25-hydroxyvitamin D correlate better with bone density than serum total 25-hydroxyvitamin D. Scandinavian Journal of Clinical and Laboratory Investigation 201474 177-183. (https://doi.org/10.3109/00365513.2013.869701)

23 Safadi FF, Thornton P, Magiera H, Hollis BW, Gentile M, Haddad JG, Liebhaber SA \& Cooke NE. Osteopathy and resistance to vitamin D toxicity in mice null for vitamin D binding protein. Journal of Clinical Investigation 1999103 239-251. (https://doi.org/10.1172/JCI5244)

24 Tsuprykov O, Chen X, Hocher CF, Skoblo R, Yin L \& Hocher B. Why should we measure free $25(\mathrm{OH})$ vitamin D? Journal of Steroid Biochemistry and Molecular Biology 2018180 87-104. (https://doi. org/10.1016/j.jsbmb.2017.11.014)

25 Powe CE, Evans MK, Wenger J, Zonderman AB, Berg AH, Nalls M, Tamez H, Zhang D, Bhan I, Karumanchi SA, et al. Vitamin D-binding protein and vitamin D status of black Americans and white Americans. New England Journal of Medicine 2013369 1991-2000. (https://doi. org/10.1056/NEJMoa1306357)

26 Holick MF. Bioavailability of vitamin D and its metabolites in black and white adults. New England Journal of Medicine 2013369 2047-2048. (https://doi.org/10.1056/NEJMe1312291)

27 Aloia J, Mikhail M, Dhaliwal R, Shieh A, Usera G, Stolberg A, Ragolia L $\&$ Islam S. Free $25(\mathrm{OH}) \mathrm{D}$ and the vitamin D paradox in African Americans. Journal of Clinical Endocrinology and Metabolism 2015100 3356-3363. (https://doi.org/10.1210/JC.2015-2066)

28 Lee MJ, Kearns MD, Smith EM, Hao L, Ziegler TR, Alvarez JA \& Tangpricha V. Free 25-hydroxyvitamin D concentrations in cystic fibrosis. American Journal of the Medical Sciences $2015350374-379$. (https://doi.org/10.1097/MAJ.0000000000000592)

29 General authority for statistics Kingdom of Saudi Arabia. Riyadh, Saudi Arabia: General Authority for Statistics. (available at: https:// www.stats.gov.sa/en)

30 Ross AC, Manson JE, Abrams SA, Aloia JF, Brannon PM, Clinton SK, Durazo-Arvizu RA, Gallagher JC, Gallo RL, Jones G, et al. The 2011 report on dietary reference intakes for calcium and vitamin $\mathrm{D}$ from the Institute of Medicine: what clinicians need to know. Journal of Clinical Endocrinology and Metabolism 201196 53-58. (https://doi.org/10.1210/ jc.2010-2704)

31 Ardawi MS, Qari MH, Rouzi AA, Maimani AA \& Raddadi RM. Vitamin $D$ status in relation to obesity, bone mineral density, bone turnover markers and vitamin D receptor genotypes in healthy Saudi pre-and postmenopausal women. Osteoporosis International 201122 463-475. (https://doi.org/10.1007/s00198-010-1249-7)

32 Fitzpatrick T. Peau et soleil. Journal of Medical Esthetics 19752 33-34.

33 Strath SJ, Kaminsky LA, Ainsworth BE, Ekelund U, Freedson PS, Gary RA, Richardson CR, Smith DT, Swartz AM \& American Heart Association Physical Activity Committee of the Council on Lifestyle and Cardiometabolic Health and Cardiovascular, Exercise, Cardiac Rehabilitation and Prevention Committee of the Council on Clinical Cardiology, and Council. Guide to the assessment of physical activity: clinical and research applications: a scientific statement from the American Heart Association. Circulation 2013128 2259-2279. (https:// doi.org/10.1161/01.cir.0000435708.67487.da)

34 Zareef TA, Jackson RT \& Alkahtani AA. Vitamin D intake among premenopausal women living in Jeddah: food sources and relationship to demographic factors and bone health. Journal of Nutrition and Metabolism 20182018 8570986. (https://doi.org/10.1155/2018/8570986)
35 Friedewald WT, Levy RI \& Fredrickson DS. Estimation of the concentration of low-density lipoprotein cholesterol in plasma, without use of the preparative ultracentrifuge. Clinical Chemistry 1972 18 499-502. (https://doi.org/10.1093/clinchem/18.6.499)

36 World Health Organization. Obesity: preventing and managing the global epidemic. In Report of a WHO Consultation. WHO Technical Report Series No. 894. Geneva: WHO, 2000.

37 World Health Organization. Waist circumference and waist-hip ratio. In Report of a WHO Expert Consultation. Geneva: WHO, 2008.

38 Schwartz JB, Lai J, Lizaola B, Kane L, Markova S, Weyland P, Terrault NA, Stotland N \& Bikle D. A comparison of measured and calculated free $25(\mathrm{OH})$ vitamin D levels in clinical populations. Journal of Clinical Endocrinology and Metabolism 201499 1631-1637. (https://doi.org/10.1210/jc.2013-3874)

39 Nielson CM, Jones KS, Chun RF, Jacobs JM, Wang Y, Hewison M, Adams JS, Swanson CM, Lee CG, Vanderschueren D, et al. Free 25-hydroxyvitamin D: impact of vitamin D binding protein assays on racial-genotypic associations. Journal of Clinical Endocrinology and Metabolism 2016101 2226-2234. (https://doi.org/10.1210/jc. 2016-1104)

40 Holick MF, Siris ES, Binkley N, Beard MK, Khan A, Katzer JT, Petruschke RA, Chen E \& Depapp AE. Prevalence of vitamin D inadequacy among postmenopausal North American women receiving osteoporosis therapy. Journal of Clinical Endocrinology and Metabolism 200590 3215-3224. (https://doi.org/10.1210/jc.2004-2364)

41 Heaney RP, Dowell MS, Hale CA \& Bendich A. Calcium absorption varies within the reference range for serum 25-hydroxyvitamin $\mathrm{D}$. Journal of the American College of Nutrition 200322 142-146. (https:// doi.org/10.1080/07315724.2003.10719287)

42 Leaf DE, Waikar SS, Wolf M, Cremers S, Bhan I \& Stern L. Dysregulated mineral metabolism in patients with acute kidney injury and risk of adverse outcomes. Clinical Endocrinology 201379 491-498. (https:// doi.org/10.1111/cen.12172)

43 Oleröd G, Hultén LM, Hammarsten O \& Klingberg E. The variation in free 25-hydroxy vitamin D and vitamin D-binding protein with season and vitamin D status. Endocrine Connections 20176 111-120. (https:// doi.org/10.1530/EC-16-0078)

44 Goswami R, Saha S, Sreenivas V, Singh N \& Lakshmy R. Vitamin D-binding protein, vitamin D status and serum bioavailable 25 $(\mathrm{OH}) \mathrm{D}$ of young Asian Indian males working in outdoor and indoor environments. Journal of Bone and Mineral Metabolism 201735 177-184. (https://doi.org/10.1007/s00774-016-0739-x)

45 Carlsson M, Brudin L \& Wanby P. Directly measured free 25-hydroxy vitamin D levels show no evidence of vitamin D deficiency in young Swedish women with anorexia nervosa. Eating and Weight Disorders 201823 247-254. (https://doi.org/10.1007/s40519-017-0392-y)

46 Jemielita TO, Leonard MB, Baker J, Sayed S, Zemel BS, Shults J, Herskovitz R \& Denburg MR. Association of 25-hydroxyvitamin D with areal and volumetric measures of bone mineral density and parathyroid hormone: impact of vitamin D-binding protein and its assays. Osteoporosis International 201627 617-626. (https://doi. org/10.1007/s00198-015-3296-6)

47 El Sabeh M, Ghanem P, Al-Shaar L, Rahme M, Baddoura R, Halaby G, Singh RJ, Vanderschueren D, Bouillon R \& El-Hajj Fuleihan G. Total, bioavailable, and free $25(\mathrm{OH}) \mathrm{D}$ relationship with indices of bone health in elderly: a randomized controlled trial. Journal of Clinical Endocrinology and Metabolism 2021106 e990-e1001. (https://doi. org/10.1210/clinem/dgaa780)

48 Kritchevsky SB, Tooze JA, Neiberg RH, Schwartz GG, Hausman DB, Johnson MA, Bauer DC, Cauley JA, Shea MK, Cawthon PM, et al. 25-Hydroxyvitamin $\mathrm{D}$, parathyroid hormone, and mortality in black and white older adults: the health ABC study. Journal of Clinical Endocrinology and Metabolism 201297 4156-4165. (https://doi. $\operatorname{org} / 10.1210 /$ jc.2012-1551)

49 Wright NC, Chen L, Niu J, Neogi T, Javiad K, Nevitt MA, Lewis CE \& Curtis JR. Defining physiologically 'normal' vitamin D in African https://ec.bioscientifica.com https://doi.org/10.1530/EC-21-0445
(C) 2021 The authors Published by Bioscientifica Ltd

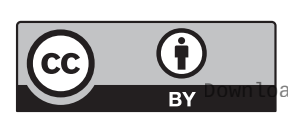

This work is licensed under a Creative Commons Attribution 4.0 International License. ded from Bioscientifica com at 04/26/2023 12:22:54PM 
Americans. Osteoporosis International 201223 2283-2291. (https://doi. org/10.1007/s00198-011-1877-6)

50 Wang L, Song Y, Manson JE, Pilz S, März W, Michaëlsson K, Lundqvist A, Jassal SK, Barrett-Connor E, Zhang C, et al. Circulating 25-hydroxy-vitamin D and risk of cardiovascular disease: a meta-analysis of prospective studies. Circulation: Cardiovascular Quality and Outcomes 20125 819-829. (https://doi.org/10.1161/ CIRCOUTCOMES.112.967604)

51 Lee JH, Gadi R, Spertus JA, Tang F \& O’Keefe JH. Prevalence of vitamin $D$ deficiency in patients with acute myocardial infarction. American Journal of Cardiology 2011107 1636-1638. (https://doi.org/10.1016/j. amjcard.2011.01.048)

52 Jorde R \& Grimnes G. Vitamin D and metabolic health with special reference to the effect of vitamin D on serum lipids. Progress in Lipid Research 201150 303-312. (https://doi.org/10.1016/j. plipres.2011.05.001)

53 Kim SM, Lutsey PL \& Michos ED. Vitamin D and cardiovascular disease can novel measures of vitamin D status improve risk prediction and address the vitamin D racial paradox? Current Cardiovascular Risk Reports 201711 3. (https://doi.org/10.1007/s12170-017-0528-7)

54 Holick MF \& Chen TC. Vitamin D deficiency: a worldwide problem with health consequences. American Journal of Clinical Nutrition 2008 87 1080S-1086S. (https://doi.org/10.1093/ajcn/87.4.1080S)

55 Armas LA, Dowell S, Akhter M, Duthuluru S, Huerter C, Hollis BW, Lund R \& Heaney RP. Ultraviolet-B radiation increases serum 25-hydroxyvitamin D levels: the effect of UVB dose and skin color. Journal of the American Academy of Dermatology 200757 588-593. (https://doi.org/10.1016/j.jaad.2007.03.004)

56 Webb AR, Kline L \& Holick MF. Influence of season and latitude on the cutaneous synthesis of vitamin D3: exposure to winter sunlight in Boston and Edmonton will not promote vitamin D3 synthesis in human skin. Journal of Clinical Endocrinology and Metabolism 198867 373-378. (https://doi.org/10.1210/jcem-67-2-373)

57 Webb AR, Pilbeam C, Hanafin N \& Holick MF. An evaluation of the relative contributions of exposure to sunlight and of diet to the circulating concentrations of 25-hydroxyvitamin D in an elderly nursing home population in Boston. American Journal of Clinical Nutrition 199051 1075-1081. (https://doi.org/10.1093/ajcn/51.6.1075)

58 Shoenfeld N, Amital H \& Shoenfeld Y. The effect of melanism and vitamin D synthesis on the incidence of autoimmune disease. Nature Clinical Practice: Rheumatology 20095 99-105. (https://doi. org/10.1038/ncprheum0989)

59 Tsiaras WG \& Weinstock MA. Factors influencing vitamin D status. Acta Dermato-Venereologica 201191 115-124. (https://doi. org/10.2340/00015555-0980)

60 Fuleihan GE-H. Vitamin D deficiency in the Middle East and its health consequences for children and adults. Clinical Reviews in Bone and Mineral Metabolism 20097 77-93. (https://doi.org/10.1007/s12018-0099027-9)

61 Matsuoka LY, Ide L, Wosman J, Maclaughlin JA \& Holick MF. Sunscreens suppress smcutaneous vitamin D3 synthesis. Journal of Clinical Endocrinology and Metabolism 198764 1165-1168. (https://doi. org/10.1210/jcem-64-6-1165)

62 Saadi HF, Nagelkerke N, Benedict S, Qazaq HS, Zilahi E, Mohamadiyeh MK \& Al-Suhaili AI. Predictors and relationships of serum 25 hydroxyvitamin D concentration with bone turnover markers, bone mineral density, and vitamin D receptor genotype in Emirati women. Bone 200639 1136-1143. (https://doi.org/10.1016/j. bone.2006.05.010)

63 Mishal AA. Effects of different dress styles on vitamin D levels in healthy young Jordanian women. Osteoporosis International 200112 931-935. (https://doi.org/10.1007/s001980170021)

Received in final form 4 November 2021

Accepted 15 November 2021

Accepted Manuscript published online 16 November 2021

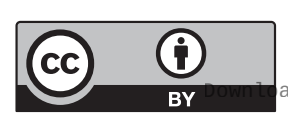

This work is licensed under a Creative Commons Attribution 4.0 International License.

ded from Bioscientifica.com at 04/26/2023 12:22:54PM 